\title{
THE AFFECTIVE DIRECTIVES OF THE BOOK OF REVELATION ${ }^{1}$
}

\author{
Andrew Harker
}

\begin{abstract}
Summary
In contemporary study of the Johannine Apocalypse both at the academic and popular levels there continues to be a strong bias towards questions of hermeneutics and semantics. This is true despite the calls of many commentators and pastors over the last two millennia to receive the prophecy as pictures to move the heart rather than puzzles to tease the mind. This paper adds volume and clarity to their call. The approach here is an emic one-How does the text itself invite the recipient to engage with its words? Picking up on J.-P. Ruiz's suggestion that Revelation is punctuated by 'hermeneutical imperatives' (sc. Rev. 1:3; 2:7, 11, 17, 29; 3:6, 13, 22; 13:9-10, 18; 17:9; 22:7, 18-19), this article argues that these texts are just as much, if not more, 'affective imperatives' or better 'affective directives'. Thus to read the book in line with its own explicit directions is much more a matter of being moved at the level of the heart and will than of solving a hermeneutical conundrum.
\end{abstract}

\section{Introduction}

Teach on Revelation or even mention the book in conversation and the most common question you are likely to receive is, "What does it mean?' or, perhaps specifically related to a particular portion, 'What exactly is the ...' Less common is the question, 'How is the text trying to move me as its hearer?' It is true that since the 1980s Revelation has

\footnotetext{
1 The first two sections of this article draw largely on this writers' unpublished doctoral dissertation 'Spiritually called Sodom and Egypt: Getting to the Heart of Early Christian Prophecy through the Apocalypse of John' (London School of Theology, 2011).
} 
been subject to a good deal of very fruitful rhetorical analysis but even this often tends to be used as a means to a hermeneutical end. ${ }^{2}$ C. Rowland has recently noted the danger in Revelation scholarship, as in the study of William Blake's work, 'that the poetry and pictures in the end are in danger of becoming just an elaborate political allegory, comprehensible only against the peculiarities of a a [sic] reconstructed historical setting, ${ }^{3}$

In contrast, one of the earliest commentators Dionysius received the Johannine Apocalypse not as a source of information but of wonder $(\theta \alpha v \mu \alpha-)^{4}$ and blessing $(\mu \alpha \kappa \alpha \rho-){ }^{5}$ Fourteen centuries later J. Durham noted the persuasive force of Revelation 2-3 and found there a model for preaching that is 'pathetic, pungent and weighty', that 'rips up the heart'. ${ }^{6}$ Modern scholarship has noted a similar quality. J. Sweet describes the impact as 'more like music than rational discourse ... a total effect which is emotional as much as rational'. ${ }^{7}$ A. Yarbro Collins finds that the text is both 'commissive language' that calls for 'commitment to the actions, attitudes, and feelings uttered' and 'evocative' language that 'elicits' particular 'attitudes and feelings' ${ }^{8}$ A. D. Callahan notes that the experience of 'hearing the Apocalypse read aloud, was effectual: through exhortations and exclamations, threat and thunder, the reading of the Apocalypse moved its hearers, affected them; the text did something to them'.

This paper argues that these latter testimonies to the effect of Revelation are not arbitrary reader responses but are in line with the

2 E.g. note the title of David Arthur deSilva's paper, 'A Sociorhetorical Interpretation of Revelation 14:6-13: A Call to Act Justly toward the Just and Judging God', Bulletin for Biblical Research 9 (1999): 65-117. Here deSilva follows V. K. Robbins' five 'textures'. He 'explores', 'analyses' and 'investigates' each but arguably does not feel the textures. Fear and gratitude are understood within the Roman patronage system as discharging an obligation to honour (deSilva, 'A Sociorhetorical Interpretation', 82, 98).

3 C. Rowland, "Rouzing the faculties to act": William Blake, Merkabah Mysticism, the Theology of Liberation and the Exegetical Importance of Experience', Biblical Interpretation 11.3-4 (2003): 552.

4 Eusebius, Eccl. Hist. 7:25. Cf. Rev. 17:6-8.

5 Eusebius, Eccl. Hist. 7:26b. Cf. Rev. 1:3.

6 James Durham, Commentary Upon the Book of the Revelation (First Published 1658) (Willow Street: Old Paths Publications, 2000): 329.

7 John Sweet, Revelation (London: SCM, 1979): 13.

8 A. Yarbro Collins, Crisis and Catharsis: The Power of the Apocalypse (Philadelphia: Westminster, 1984): 144, emphasis original.

9 Quoted by Ben Witherington III, Revelation (Cambirdge: Cambridge University Press, 2003): 17. 
intended effect of the text. It is necessary at this point to move from etic perspectives to an emic account, from Wirkungsgeschichte and external categories to the internal testimony of the text itself-How does the text ask to be read?

J.-P. Ruiz has done some very important work in this regard. He finds that Revelation is punctuated by what he calls 'hermeneutical imperatives'. He is not referring particularly to morphological imperatives (his examples of Rev. 1:3; 13:10; 17:9; 22:7, 18-19 do not contain verbs in the imperative mood) but to meta-communication (that is parts of the text that reflect on the communication going on between text and hearer) that function as a call to the reader to carefully puzzle over the text and give guidelines for its interpretation. ${ }^{10}$ It may be best to call these 'directives' - both in the technical sense of Speech Act Theory in that these statements 'count as' directives ${ }^{11}$ and in the looser sense that these statements direct the hearer/reader, whether in their approach to the text or some other way.

It will be argued here that each of the 'hermeneutical' imperatives/directives given by Ruiz is better understood as an affective directive - they are appealing for heart-engagement with the text rather than simply mind-engagement. A similar critique of Ruiz has been made relatively briefly by G. K. Beale. ${ }^{12}$ Some might consider Beale's response sufficient but there are two reasons for adding this present paper:

1) Greater volume. Judging by the continued bias towards an exclusive focus on hermeneutical questions in relation to Revelation, it seems well worth amplifying and adding new arguments to those of Beale.

2) Greater clarity. This paper differs slightly from Beale in using the terminology of 'affective directives'. Beale speaks of 'volitional',

10 Jean-Pierre Ruiz, Ezekiel in the Apocalypse: The Transformation of Prophetic Language in Revelation 16,17-19,10 (Frankfurt am Main: Peter Lang, 1989): 190-211.

11 The seminal work here is that of John Langshaw Austin, How to Do Things with Words (2nd edn; Oxford: Oxford University Press, 1975) with elaboration particularly by John R Searle and Daniel Vanderveken, Foundations of Illocutionary Logic (Cambridge: Cambridge University Press, 1985). It is acknowledged there is a debate to be had about whether there are sufficient controls over the assigning of illocutionary force and the interpretation of an utterance as 'counting as' another form of utterance (Richard S. Briggs, Words in Action: Speech Act Theory and Biblical Interpretation (Edinburgh: T\&T Clark, 2001).

12 Gregory K Beale, John's Use of the Old Testament in Revelation (Sheffield: Sheffield Academic Press, 1998): 33-37. 
'moral' and 'ethical' imperatives. First, as noted above, technically these are not all imperatives. More importantly R. Waddell has criticised Beale for demarcating 'too drastically the difference between propositional cognitive elements of truth and existential volitional realization of truth'. ${ }^{13}$ Waddell's critique is fair but he does not provide an alternative grammar for speaking about heart response to a text. This article employs J. Edwards' definition of 'the affections' which has the advantage of avoiding any sharp distinction between cognitive and volitional elements while emphasising that which is wider and further than mere perception/cognition.

\section{Defining Affect}

Jonathan Edward's Treatise Concerning the Religious Affections (1746) is indisputably one of the most important works in the English language on the subject and it provides a clear vocabulary and grammar of affection particularly suited to theological literature. Edwards defines the affections as 'the more vigorous and sensible exercises of the inclination and will of the soul'. ${ }^{14}$ By 'vigorous and sensible' Edwards means 'lively actings ... fervent exercises of the heart' ${ }^{15}$ that are 'very much the spring of mens [sic] actions'. ${ }^{16}$ By 'inclination and will' he means the faculty

by which the soul does not merely perceive and view things, but is some way inclined with respect to the things it views or considers; either is inclined to them, or is disinclined and averse from them; or is the faculty by which the soul does not behold things, as an indifferent unaffected spectator, but either as liking or disliking, pleased or displeased, approving or rejecting. This faculty is called by various names; it is sometimes called the inclination: and, as it has respect to the actions that are determined and governed by it, is called the will: and the mind, with regard to the exercises of this faculty, is often called the heart. ${ }^{17}$

13 Robby Waddell, The Spirit of the Book of Revelation (Blandford Forum: Deo, 2006): 89.

14 Jonathan Edwards, Treatise Concerning Religious Affections, in Three Parts (Philadelphia: James Crissy, 1821): 16.

15 Edwards, Religious Affections, 20.

16 Edwards, Religious Affections, 22.

17 Edwards, Religious Affections, 16-17 (emphasis original). 
There is no room here for a thorough discussion and defence of the usefulness of Edward's definition but three points are particularly important:

1) It is clear from the quote above that, for Edwards, affection is largely binary-it is repulsion or attraction with respect to an object. This understanding is identical to that of Augustine (De Civ. 14:6). As Edwards elaborates his definition (p. 16-19 of his treatise) he gives a series of binary descriptions and examples of the affections:

Inclined towards
Cleaving to
Seeking, longing for
Liking
Pleased
Approving
Approbation
Love, desire
Complacence
Gratitude
Joy, delight

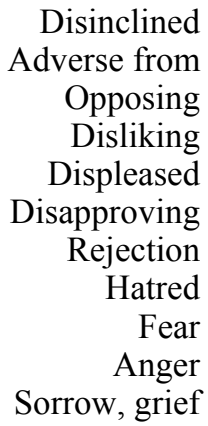

Edwards makes a further binary distinction, again following in the footsteps of Augustine (De Civ. 14:7), between affections that are gracious, holy and spiritual and those affections that are not. The objective difference between the two consists in their objects: spiritual affections are directed towards 'divine things' and especially their holiness and against their negation; unspiritual affections are directed towards the self and all that pertains to it and against divine and holy things. ${ }^{18}$ Thus Edward's account of affection is much more objectfocused than many contemporary psychological understandings of affect as including mood, an objectless state.

2) Affective force is to be distinguished from superficial emotional stimulation. While they involve emotion, affections are not to be confused with the passions in the ancient Graeco-Roman rhetorical sense or emotion in the modern psychological sense. While catharsis of passions can be achieved through music (Aristotle, Politica 8:7), ${ }^{19}$ and modern science has found that emotion and mood can be induced

\footnotetext{
18 Edwards, Religious Affections, 179-208.

19 Walker J. Walker, "Pathos and Katharsis in "Aristotelian" Rhetoric: Some Implications' in A. G. Gross and A. E. Walzer, eds., Rereading Aristotle's Rhetoric (Carbondale: SIUP, 2000): 77.
} 
through chemical means ${ }^{20}$ or even the stimulation of facial muscles, ${ }^{21}$ affection involves the movement of the whole person at a much deeper level-heart, soul, strength. Affection may be unspiritual but it will never be shallow.

3) Affections are also to be distinguished from pure cognition - the faculty of the soul (to use Edwards' language) 'capable of perception and speculation, or by which it discerns, and views, and judges of things; which is called the understanding'. ${ }^{22}$ Cognition is not divorced from affection and is almost invariably dependent on it: 'Holy affections are not heat without light; but evermore arise from the information of the understanding. ${ }^{23}$ Hermeneutics and affection are intimately related. The point is that affection 'does not merely perceive and view things'. ${ }^{24}$

\section{The Directives}

Each of the meta-communication texts identified by Ruiz will be addressed in turn to demonstrate their call is not only or chiefly to the critical faculties but to the inclination of the whole person.

\subsection{Revelation 1:3; 22:7}

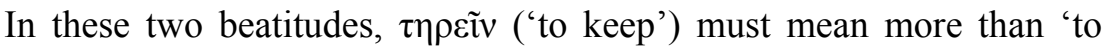
preserve faithfully and to protect against falsification'. ${ }^{25} \mathrm{D}$. Aune assembles an impressive list of parallels in the New Testament and extra-canonical literature where 'hear and keep' has the sense 'hear and obey'. ${ }^{26}$ Certainly when the object of 'keeping' is 'the commandments

20 So Antonio R. Damasio, Descartes' Error: Emotion, Reason, and the Human Brain (London: Macmillan, 1994): 121-22, 160.

21 Damasio, Error, 148.

22 Edwards, Religious Affections, 16.

23 Edwards, Religious Affections, 208 cf. p. 45. In the case of unspiritual affections the stimulus is still cognitive-'strong ideas' (Edwards, Religious Affections, 210). Edwards does however allow for affections arising from immediate sensation of the presence and power of God (or Satan) outside of normal cognitive processes (Edwards, Religious Affections, 62-67).

24 Edwards, Religious Affections, 16.

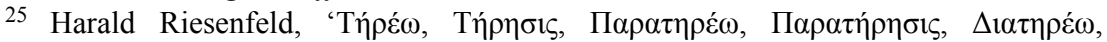
$\Sigma v v \tau \eta \rho \varepsilon ́ \omega$ ' in Theological Dictionary of the New Testament, ed. Gerhard Kittel and Gerhard Friedrich (vol. VIII; Grand Rapids: Eerdmans, 1972): 145.

26 David Edward Aune, Revelation 1-5 (WBC; Nashville: Thomas Nelson, 1997): 11, 19-20. 
of God' the united testimony of New Testament and Masoretic Text suggests the sense of actively living out. ${ }^{27}$ In Deuteronomy, where the phrase occurs over thirty times, to keep the commandments of God is 'to do them, to love the LORD your God, to walk in all his ways, and to cleave unto him' (Deut. 11:22).

Further, it may be noted that almost every time Deuteronomy talks of keeping God's commandments, the imperative is connected to a promise of blessing-likewise in Revelation 1:3 and 22:7. If these makarisms do indeed carry the flavour of Deuteronomy then they may be taken as not only ascribing honour ('Honoured is the one who ...') and so moving the affections and inclinations of the hearers towards obedience, ${ }^{28}$ but also invoking an actual blessing - a foretaste of eschatological joy and gladness (cf. Deut. 12:7, 12, 18; 14:26; 16:11, $14-15 ; 26: 11 ; 27: 7 ; 33: 29$; Rev. 1:3d; 19:7). In the terminology of Speech Act Theory the utterance not only counts as a directivecalling the reader to hear and keep the words that follow-but also performs illocutionary acts of promise (commissive) and blessing (declarative) $)^{29}$ that, under the right conditions, ${ }^{30}$ result in the hearer actually being brought into a state of blessedness.

The Deuteronomic background to the two makarisms is probably mediated through Psalm 1:1-3 ${ }^{31}$ where reading/hearing God's law is 'delight' (Ps. 1:2), likened to a tree drinking from a stream of lifegiving water (Ps. 1:3 cf. Rev. 21:6; 22:1-2).

To talk of loving, cleaving, joy and delight is to talk about the affections. The opening makarism of Revelation thus directs the hearer to expect all of 'the words of the prophecy' (Rev. 1:3) to be affective in this way, while at the close of the book (Rev. 22:7) the hearer is reminded of this purpose.

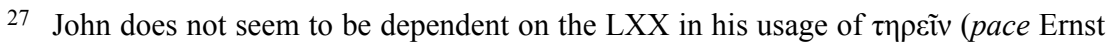
Lohmeyer, Die Offenbarung des Johannes (Tübingen: Mohr Siebeck, 1953): 9).

28 Cf. the argument of David Arthur deSilva, 'Honor Discourse and the Rhetorical Strategy of the Apocalypse of John', JSNT 71 (1998): 105.

29 Or 'exercitive' to use the original terminology of Austin, Words, 154.

30 'Institutional facts' and 'brute facts', e.g. the reality of the divine agent and covenant guaranteeing events (see Roger Lundin et al., The Promise of Hermeneutics (Grand Rapids: Eerdmans, 1999): 30-32, 36, 147, 227-28). One might add the condition that the hearer continues in the path of holiness, righteousness, endurance and faithfulness.

31 Lohmeyer, Offb. Joh., 9 sees Ps. 1:1-3 as determinative of both Rev. 1:3//22:7 and Luke 11:28. 


\subsection{Revelation 22:18-19}

This is not simply an 'integrity formula' aimed at the lax or unfaithful scribe but affective rhetoric addressed to 'everyone who hears [not 'reads'32 or 'writes'33] the words of the prophecy of this book' (Rev. 22:18 emphasis added). As long ago as the Sixth Century Primasius of Hadrumetum commented that this passage adds the 'terror of the plagues' to 'urge and warn ... move the idle with threats or restrain the reckless' ${ }^{34}$ Beale has shown not only that that Revelation's formula draws heavily on Deuteronomy (sc. Deut. 4:1-2; 12:32; 29:19-20) but that the original contexts (sc. 'warning against deceptive teaching which affirmed that idolatry was not inconsistent with faith in the God of Israel') resonate strongly with the message of Revelation (cf. Rev. $2: 14,20) .{ }^{35}$ So Revelation 22:18-19 functions as a dramatic call to flee idolatry and the awful fate of idolaters (Rev. 21:8; 22:15) by clinging to the true God and the Lamb and his redeeming sacrifice and thereby enjoying the joys of the New Creation (Rev. 20:15; 21:6-7, 27; 22:14, 17). Furthermore, the Deuteronomic allusions of Revelation 22:18-19, in presenting 'Revelation as a new law code to a new Israel' ${ }^{36}$, imply that the whole prophecy is truth disclosed in order to be practised (cf. Deut. 29:29) - thus reinforcing the understanding of $\tau \eta \rho \varepsilon \tilde{v}$ in Revelation 1:3//22:7 argued above.

Interestingly, many of the other 'integrity formulae' of ancient literature often cited in comparison to Revelation 22:18-19 are also rather more affective than hermeneutical or scribal imperatives. For example, in 2 Enoch $48: 6-8,{ }^{37}$ to receive the books of revelation is to 'love them more than any food or earthly sweets', to not only read but to 'apply'. Conversely, not to receive is to 'understand not the Lord', a

32 Cf. 2 En. 48:6.

33 Cf. 1 En. 104:11.

34 Quoted in William C Weinrich, Ancient Christian Commentary on Scripture: New Testament - Revelation (vol. 12; Downers Grove: IVP, 2006): 408.

35 Beale, John's Use, 95-98; cf. similarly Stephen S Smalley, The Revelation to John: A Commentary on the Greek Text of the Apocalypse (London: SPCK, 2005): 584.

36 Beale, John's Use, 95. Cf. Deut. 4:1-2; 12:32; 29:19-20.

37 Cited e.g. by Robert Henry Charles, A Critical and Exegetical Commentary on the Revelation of St John (vol. II; Edinburgh: T\&T Clark, 1920): 223; George Bradford Caird, A Commentary on the Revelation of St. John the Divine (London: Black, 1966): 287; Isbon Thaddeus Beckwith, The Apocalypse of John: Studies in Introduction with a Critical and Exegetical Commentary (Grand Rapids: Baker, 1979): 779; Ruiz, Ezekiel, 194. The translation from the Slavonic following is that of W. R. Morfill (1896) edited by R. H. Charles and in the public domain. 
clause which is not speaking of a failure of hermeneutics but is explained as to 'fear not God', to 'accept not, but reject' (note the binary language). A blessing is on the man who 'shall bear their yoke' - that is the one who not only understands but feels the weight of the books as Torah.

\subsection{Revelation 2:7, 11, 17, 29; 3:6, 13, 22}

The call to hear repeated toward the close of each of the seven proclamations certainly demands, as Ruiz notes, 'particularly attentive reflection' 38 but not only this. As Ruiz himself explains, the call has a note of 'eschatological urgency' ('Hear now, before it is too late!') and of 'divine authority' ('Hear the word of the Lord God himself!') ${ }^{39}$ imperatives aimed at the heart. Furthermore, 'analogous to the Hebrew שמע, the admonition in the hearing formula implies heeding as well as hearing', ${ }^{40}$ Thus it underlines the warnings and exhortations of the proclamations to have a change of heart, not to fear, not to be lukewarm, but to return to the first love and to hate idolatry. That heart and will are involved is confirmed by 13:9-10 where the call to hear seems to be equated with endurance and faith.

13:1-8 Visionary narrative depicting the suffering of God's people 13:9 'Let him hear' 13:10ab Prophecy predicting the suffering of God's people $13: 10 \mathrm{c}$ 'This is the endurance and faith'

Beale notes the close connection between the hearing formula and parabolic language both in the major Old Testament prophets and in the Synoptics (esp. Mark 4:10-12 par.) - a connection which suggests that the call to hear will have the twofold effect of hardening the already calloused majority (cf. Rev. 22:11ab) and awakening the remnant from spiritual lethargy. ${ }^{41}$ In this context the hearing formula is aimed 'more at ... the heart' 42 with the affective force of shaking the hearer and shouting 'Wake up!' As Beale puts it, the effect is 'jolting', 'jarring', 'shock', 'piercing to the heart'. ${ }^{43}$

38 Ruiz, Ezekiel, 198.

39 Ruiz, Ezekiel, 198-99.

40 Waddell, Spirit, 88-89. As at Deut. 1:43; 4:30; 6:4-5; 8:20; 11:13, 27, 28; 12:23; $13: 4 ; 21: 18,20 ; 26: 17 ; 18: 1,2,13,15,45,62 ; 30: 2,8,10,20$.

41 Beale, John's Use, 306-10 cf. similarly Ian Paul, 'The Value of Paul Ricoeur's Hermeneutic of Metaphor in Interpreting the Symbolism of Revelation Chapters 12 and 13' (Ph.D. dissertation, Nottingham Trent University, 1998): 2 esp. n. 3.

42 Beale, John's Use, 35.

43 Beale, John's Use, 11, 307-308. 


\subsection{Revelation 13:9-10}

Ruiz argues that the hearing formula in 13:9 not only refers back to the preceding symbolic discourse (as is normally the case with the hearing formula in the Synoptics and Rev. 2-3) but also points forward to the maxim at 13:10ab. ${ }^{44}$ According to Ruiz, this maxim is an allusive interpretative key to the discourse of $13: 1-8 .{ }^{45}$ So the imperative of 13:9-10 is to pick up a hermeneutical key and engage it to unlock the preceding vision.

The question of what constitutes 'interpretation' is a difficult one $e^{46}$ but it may be noted here that:

1) Jeremiah 15:2 (the primary allusion of Rev. 13:10ab) does not straightforwardly 'unlock' Revelation 13:1-8. In fact there is a good deal of tension between Jeremiah's prophecy of judgement for the unfaithful ${ }^{47}$ and Revelation 13:1-8 (with its Danielic background) which concerns the persecution of the faithful.

2) Rather than helping with questions of reference (who, what, when, where), the main function of 13:10 is simply to invoke the affective force of the Exile so as to drive home themes already raised in 13:1-8 - the inevitability of being trampled, the reality and awfulness of this coming event, and God's complete sovereignty over it. Rather than shedding great hermeneutical light on the preceding vision, 13:10 is piling on affective weight-horror, sorrow and grief. A modern analogy to the process here might be when a journalist describes a refugee camp as a scene from hell. The journalist is not giving us a key to interpret the situation, he does not mean to imply that the refugees are there deservedly or eternally — he is simply using the powerful affective associations of the word to relay the horror of the scene.

\subsection{Revelation 13:18}

In this verse and the final text, Revelation 17:9, Ruiz seems to have some of his best evidence for hermeneutical imperatives. Both verses collocate oopía (wisdom) and voũs (mind). However, it is unlikely that John is calling for the application of 'intelligence' in 'the human

\footnotetext{
44 Ruiz, Ezekiel, 203. Cf. also the punctuation of Rev. 13:9-10 by the ESV.

45 So Ruiz, Ezekiel, 203.

46 Cf. the running debate between S. Moyise and G. K. Beale.

47 If Jer. 43:11 is also in view the dissonance is even greater-in Jer. 43 it is Egypt being judged.
} 
activity of deciphering, interpreting and understanding' ${ }^{48}$ Beale $^{49}$ (and earlier Charles $)^{50}$ note that Revelation's collocation of oopía and voũs invokes a Danielic background where wisdom and insight is for the purpose of interpreting dreams and visions (sc. Dan. 1:17; 2:21; 9:22$23 ; 11: 33 ; 12: 10)$. If Daniel is in view then the wisdom and understanding spoken of in Revelation 13 and 17 are not so much a 'human activity' as a divine gift; not so much 'intelligence' as spiritual discernment; not so much a call to 'ponder' as to wake up and flee the subtlety of satanic deception. ${ }^{51}$

However, it may be that for Revelation 13:11-17 the background of Daniel 3 is more important than the interpreted dreams and visions of Daniel 2, 9, 11 and 12; the connections being (a) the setting up of an image, (b) by a pagan 'world power', (c) that everyone must worship, (d) on pain of death, (e) the big question being, 'Whom will you worship?'.52 The hearers of Revelation are then not necessarily to identify themselves with Daniel interpreting a vision (Dan. 3 is not a vision requiring interpretation) but with Shadrach, Meshach and Abednego who have the wisdom to fear God and the insight to know the real Holy One (cf. Prov. 9:10) ) $^{53}$ and refuse to worship the idolatrous image.

Coming to the actual command of the verse- 'calculate the number of the beast' (Rev. 13:18b) - it might appear that surely here is a case of an imperative to strenuous mental activity and decipherment. However, two lines of argument can be taken to show that the direction is addressed as much, if not more, to the heart as to the head:

1) It is certainly quite possible that ' $\psi \eta \varphi 1 \sigma a ́ t \omega$ ' would have been heard as 'count' or 'calculate'. It is cognate with íółnpos which can refer to the practice of discerning the equal numerical values of words

48 Ruiz, Ezekiel, 207. It should be noted that Ruiz cautions that this is not 'detached intellectual speculation' but a matter of 'urgent interest to the community' (Ruiz, Ezekiel, 205).

49 Gregory K Beale, 'The Danielic Background for Revelation 13:18 and 17:9', Tyndale Bulletin 31 (1980): 163-70.

50 Robert Henry Charles, A Critical and Exegetical Commentary on the Revelation of St John (vol. I; Edinburgh: T\&T Clark, 1920): 364.

51 Beale, 'Danielic Background', 166-70.

52 The relevance of Dan. 3 continues into Rev. 14 as shown by deSilva, 'A Call to Act Justly', 85-88.

53 This verse is the closest the OT comes to a 'dictionary definition' of 'wisdom'

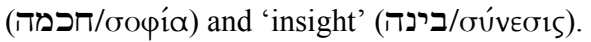


by gematria ${ }^{54}$ and the imperative is quickly followed by a number (666). Following this lead, it is found that transliterating 'Beast'

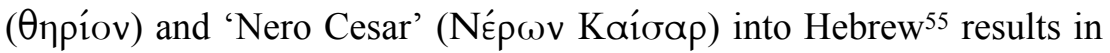
a number of 666 for both, thus demonstrating by isopsephism that Nero is the Beast. ${ }^{56}$ The strongest corroborating argument for the Nero identification is the fact that the Latin Nero Caesar transliterated in Hebrew has the value 616 , explaining a textual variant ${ }^{57}$ which perhaps testifies to early knowledge of this solution. ${ }^{58}$ Furthermore, as Lohmeyer and others have noted, 666 is a doubly triangular number. ${ }^{59}$ Bauckham suggests that triangular numbers in the Apocalypse denote evil realities in contrast to square numbers such as 144 , associated with the New Jerusalem (Rev. 21:17) which is itself a physical square (Rev. $21: 16) .{ }^{60}$

54 The lemma is not present in the biblical text but there is some evidence for the practice of isopsephy and gematria at certain points - e.g. John 21:11 (J. A. Romero, 'Gematria and John 21:11: The Children of God', JBL 97 (1978): 263-64; Richard J Bauckham, 'The 153 Fish and the Unity of the Fourth Gospel', Neot 36 (2002): 77-88; M. Kiley, 'Three More Fish Stories (John 21:11)', JBL 127 (2008): 529-31). It should be noted however that iбó in voting/judgement (LSJ) cf. Acts 26:10.

55 As Gregory K Beale, The Book of Revelation: A Commentary on the Greek Text (Grand Rapids: Eerdmans, 1999): 721 notes, John is expecting a great deal of his audience if he is requiring them to perform transliterations into Hebrew (a language only familiar to some of his audience) without any direction to do this (cf. the explicit linguistic references at Rev. 9:11; 16:16). On the other hand perhaps those frequently dealing with different alphabets (cf. Mark 5:41; 15:34; John 1:38, 42, etc.) and with an alphabetic number system would have been highly competent transliterators, and perhaps those in a (sub)culture fascinated by gematria would be well used to decoding puzzles.

56 Richard J Bauckham, The Climax of Prophecy: Studies on the Book of Revelation (London: T\&T Clark, 1993): 387-89.

57 However, this is not the only variant (Michael G. Michael, '666 or 616 (Rev. 13, 18)', Bulletin of Biblical Studies 19 (2000): 83 n.18). Other variants (e.g. 665) are not easily explained as transliterations of 'Nero Cesar'. It is possible that 616 was simply a scribal error (cf. Irenaeus, $A d v$. Her. 5.30.1) resulting from the reading of X $\Xi \zeta$ as XIS. This apparently unlikely error is rendered more likely when the MSS unical forms are observed-e.g. the witness of $\mathfrak{P}^{47}$ where the $\mathrm{Xi}$ has a strong near-vertical line and rather short top and central horizontals.

58 As pointed out in personal communication by Ian Paul (22 September 2010). Notwithstanding this evidence it is striking that the Nero solution is not evident in early Christian commentary (David Edward Aune, Revelation 6-16 (WBC; Nashville: Thomas Nelson, 1998): 770).

59 Lohmeyer, Offb. Joh., 118-19.

60 Bauckham, Climax, 384-407. Although surely the New Jerusalem is depicted as physically square because it is modelled on (a) the square outer limit of the temple area in Ezekiel 42:15-20; and (b) the cube of the Holy of Holies (cf. 1 Kgs 6:20). 
In this case the imperative would have been firstly hermeneuticencouraging subsequent reading and study of the text. There would have been no initial affective impact except perhaps to create a sense of mystery (cf. Rev. 10:4). ${ }^{61}$ However, the ultimate intention of this direction to 'calculate the number' was surely not mere puzzle solving (a form of ancient Sudoku) but rather, in dramatically unveiling the emperor $^{62}$ as the terrifying blasphemous Beast, the text is acting powerfully on the affections of the reader. Thus 'the hermeneutical imperative supports the affective'-a call to fear and reject the imperial cult. ${ }^{63}$

2) Alternatively it may be argued that there is an affective imperative in this text even on the first hearing, quite apart from any possible gematria or other numerological significance discerned in subsequent scribal study. It is possible that ' $\psi \eta \varphi 1 \sigma \alpha$ ' $t \omega$ ' is being used quite loosely to call the hearer to 'reckon' or 'assess', in a similar way to the (American) English colloquialisms, 'Go figure' and 'It all adds up'. In this case the hearer is being prepared to receive an immediate connotative impact from the final form ' $\dot{\xi} \xi \alpha$ Kó

A number of commentators conclude that there are only two ways to

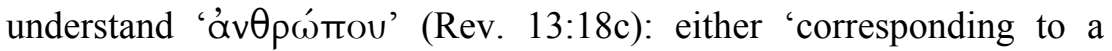
particular man' or 'humanly intelligible'. ${ }^{64}$ However, comparison with

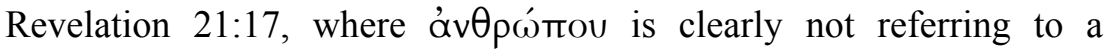
specific man, would suggest another alternative-the generic sense: 'man's number'. That man's number is 666 could be explained in a number of ways that are not mutually exclusive:

1) related to the sixth day of creation - so 6 is 'man's number';

2) contrastively related to the number 7 (indicating perfection or completeness), ${ }^{65} 6$ is the number that grasps for 7 (cf. Gen. 3:5-6; Phil.

61 Cf. the phenomenon of opaque neologisms in science fiction: 'audiences are fascinated with exotic expressions whose meanings often remain unexplained or underexplained throughout the anime' (Naoki Chiba and Hiroko Chiba, 'Words of Alienation, Words of Flight: Loanwords in Science Fiction Anime' in Robot Ghosts and Wired Dreams: Japanese Science Fiction from Origins to Anime, ed. Christopher Bolton et al. (Minneapolis: UMP, 2007): 149). I am indebted to Conrad Gempf (advisor on the NT of The Manga Bible) for this observation.

62 The current emperor or Nero Redivivus depending on the dating of Revelation.

63 The phrase is from a personal communication from Ian Paul (22 September 2010).

64 So Charles, Revelation I, 364-65; Ruiz, Ezekiel, 206; Aune, Revelation, 769.

65 On the significance of the number 7 to John see Bauckham, Climax, 29-37. The number is also clearly important to Daniel (Dan. 9 cf. 4Q390 Fr. 1:1). 
2:6) and falls short - a parody in the same way as the beasts and image of Revelation 13 parody God, the Lamb and the Spirit; ${ }^{66}$

3) alluding to the 666 talents of gold received annually by Solomon in contravention of the Deuteronomic Kingship Code (1 Kgs 10:14// 2 Chr. 9:13 cf. Deut. 17:17); ${ }^{67}$

4) alluding to the golden statue of Daniel 3:1 that was sixty cubits by six cubits (an allusion made more likely by the Dan. 3 background already noted above). ${ }^{68}$

This would cohere with the way in which numbers are normally used in the Apocalypse-symbolically, yielding instant connotations. ${ }^{69}$ The call, ' $\psi \eta \varphi 1 \sigma \alpha ́ \tau \omega$ ' could then act as a direct affective directive leading immediately (not only via later scribal mathematics) to an unveiling of the hideous Beast as man-exalting-himself-in-oppositionto-God, intended to shock those being seduced by the world and strengthen the heart resolve of the wise-towards the only true God and against imposters.

\subsection{Revelation 17:9}

Here we find Ruiz's very best example of a hermeneutical imperative/directive. Unlike Revelation 13, this context resembles that of Daniel 9, 11 and 12 in the presence of an interpreting angel explaining an obscure and troubling vision. However, even here the

66 So similarly, Leon Morris, Revelation (London: Tyndale, 1969): 174; Graham Goldsworthy, The Gospel in Revelation: Gospel and Apocalypse (Carlisle: Paternoster, 1994): 155; Ian K Boxall, The Revelation of St John (London: Continuum, 2006): 199; Simon Patrick Woodman, The Book of Revelation (London: SCM, 2008): 170-71.

67 Beale, Revelation, 727. Cf. the possibility of $1 \mathrm{Kgs} 10: 21-29$ as a background to Rev. 18:12-13 (Anthony Robert Gwyther, 'New Jerusalem Versus Babylon: Reading the Book of Revelation as the Text of a Circle of Counter-Imperial Christian Communities in the First Century Roman Empire (Online Version Pagination)' (Griffith University, 1999): 138-39).

68 In the latter two allusions we have a particular man (Solomon, Nebuchadnezzar) who is also 'representative man', king of the world (1 Kgs 10:23-24; Dan. 2:37-38; 3:4; 4:1, 22 cf. Rev. 13:7), a sort of Übermensch, an overreaching Adam at the height of his glory but also on the verge of disaster. Cf. the Edenic/Adamic depictions of the King of Babylon (Isa. 14:4-22), the King of Tyre (Ezek. 28:1-19 cf. the wisdom and wealth of Solomon), Pharaoh/Assyria (Ezek. 31:1-18 cf. Dan. 4).

69 Aune, Revelation, 773; Beale, Revelation, 721; Boxall, Revelation, 199. The number 144 is certainly square but the stress is on the number which is multiplied by itself - the number of the tribes of Israel (Rev. 7:4; 21:12) and of the apostles of the Lamb (Rev. 21:14). Similarly in the case of 666 it would appear that the stress is not on the fact that it is triangular (as opposed to square or rectangular) but on the number 6 . That 666 is the triangle of the square of six may (if anything) add even greater force to the repeated $\stackrel{\varepsilon}{\xi}$. 
main imperative may well be affective. There are strong parallels between chapters 13 and 17:

Rev. 13:1-a Beast is introduced with 7 heads, 10 horns, blasphemous names

Rev. 13:3- the Beast appears to have returned from the dead and the whole

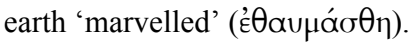

Rev. 13:8 - all who dwell on the earth whose names have not been written in the book of life before the foundation of the world will worship the Beast.
Rev. 17:3-a Beast is introduced with 7 heads, 10 horns, blasphemous names Rev. 17:6-John 'marvelled' ('̇Өaú $\mu \alpha \sigma \alpha)$ with 'great wonder' $(\theta \alpha \tilde{u} \mu \alpha)$ at the woman sitting on the Beast.

Rev. 17:7-the angel asks John why he 'marvelled' ('̇ंaúfaoas).

Rev. 17:8 - the angel says that the Beast will return from the dead and

all who dwell on the earth whose names have not been written in the book of life before the foundation of the world 'will marvel'

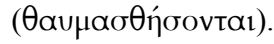

Rev. 17:9-'the mind having wisdom'.

Rev. 17:10-17 - explanation of the 7 heads and 10 horns.

It seems that marvelling is tantamount to worship and John himself (in Rev. 17:6) may have been momentarily 'captivated' by the spectacular sight of the Beast and the woman. ${ }^{70}$ The angel's question (Rev. 17:7) then functions as a rebuke (cf. Rev. 19:10; 22:9). To heed the call to wisdom, in this context, is the opposite of marvelling at that-which-isnot-God. It is to be horrified and disgusted by the beast-woman spiritual-political system and to turn instead, with the saints and martyrs (Rev. 17:6), to marvel at the true Lord God, no matter the cost.

\section{Conclusion}

Edwards' binary grammar of affections seems to fit well with John's binary visions of reality. The text presents itself as a word to delight in receiving or despair in rejecting, as a call to the heart to love and wonder at the Lord and the Lamb and to be repelled by and flee from the Beast and his prophet. The concern is not with superficial, passing emotions but deep, enduring, heart-inclinations that will hold in the face of horrific persecution.

70 Beale, John's Use, 314. 
The texts treated by Ruiz as 'hermeneutical imperatives' may be better termed affective directives. This is not to say that questions of reference and meaning are unimportant when reading (or hearing) Revelation but rather that the text's explicit directions to the reader/hearer should redress the balance in favour of a concern for how the prophecy works on the heart-inclination of those it addresses, how its shock-and-awe imagery works to wrench the affections from the enticements of idols and drives them to cleave to the all-sufficient reigning Lamb. 